\title{
Development of Video-Based on Contextual Teaching and Learning Electric Energy Subtheme
}

\section{Fariq Isy Ely Rusly}

SMKN 1 Pringapus, Central Java, Indonesia

E-mail: fariq.smkn1kabsmg@gmail.com

\section{Rifqi Aulia Erlangga}

Postgraduate Program, Islamic Education, Institut Agama Islam Negeri (IAIN) Salatiga, Central Java, Indonesia

\begin{abstract}
This study aims to develop and know the implementation of the Contextual Teaching and Learning (CTL) video about Electrical Energy Materials for Class VI Students of Islamic Elementary School. The method used in this study was Research and Development with ADDIE steps. The ADDIE is a model consisting of five steps that are Analyze, Design, Development, Implementation, and Evaluation. The study concludes that: 1) Analyze everything needed in development, 2) Design of CTL video framework in both layout and appearance, 3) Development of CTL video teaching materials from the collection of materials, preparation, validation, revision, and production of CTL videos, 4) Implementation CTL videos in learning, 5) Evaluation of the CTL video used concerning its effectiveness, practicality, and attractiveness in learning. Subjects in this research were 30 student Islamic Elementary School of Siti Sulaechah Semarang, Central Java. The data collection techniques used are interviews and questionnaires. The data analysis method in this research is qualitative and quantitative data analysis. SPSS 16 is used for quantitative analysis. The results showed as follows, 1) teachers need learning videos that are innovative, interesting, and can improve students environmental care attitudes; 2) the form of development in the form of CTL videos through the steps of analysis, design, development, application, and evaluation; and 3) Contextual Teaching and Learning-based Learning Videos can in increasing environmental attitudes (pairedsample t-test, $\alpha=0.00<0.05$ ).
\end{abstract}

Keywords: Development of Learning Videos, Contextual Teaching Learning (CTL), Elementary School 


\section{INTRODUCTION}

Educators are professionals who are tasked with planning and implementing the learning process, assessing learning outcomes, conducting mentoring and training, and conducting research and community service (Branch \& Dousay, 2015). Therefore, educators or teachers in carrying out their duties should have adequate learning planning so that learning is carried out directed, programmed, and achieve optimal results. One of the learning plans is teaching materials, which are very diverse in teaching materials, including audio teaching materials, audiovisual teaching materials, multimedia teaching materials, and printed materials (Depdiknas, 2008). One of the teaching materials that teachers can develop is the Contextual Teaching and Learning (CTL) video (Muliani \& Sumarsono, 2020; Andarini \& Masykuri, 2013).

CTL video is a form of printed teaching materials from one unit of a learning program that is packaged as a whole, systematically designed, and can be used independently to master specific learning goals (Depdiknas, 2003). Some approaches as the basis for developing CTL videos include scientific, contextual, inquiry, open-ended, process skills, and others (Irfan, 2012; Suyawati \& Osman, 2018; Zakirman \& Hidayati, 2017). Contextual is one approach that can be used as a basis for developing CTL videos (Ismatunsarrah et al., 2020; Ismatunsarrah et al., 2020 Kosassy et al., 2018). 
A contextual approach is based on how to learn constructivism, and learning is not merely memorizing, but building new knowledge and skills through real problems they experience in everyday life (Gita et al., 2018). A contextual approach can improve the ability of students in the learning process to connect information learned with real situations in everyday life (Hamdani, 2011; Selvianiresa \& Prabawanto, 2017; Siti et al., 2016). It also improves the motivation and character of the student (Rahmawati et al., 2019). Based on the description above, teachers should be able to develop CTL videos to create learning that inspires, motivates participation, provides freedom of learning for learners and increases understanding of concepts independently.

Based on the results of interviews with Mrs. Solihatun, a grade VI teacher at SD Islam Siti Sulaechah Semarang, information was obtained that there were still many students who felt that science subject matter was more difficult to understand than other subject matter. Meet the minimum completeness criteria set at a percentage of $54.55 \%$.

Observation of learning in class VI-A and VI-B obtained information that learning activities in science are still more often centered on the teacher and focuses on the completion of learning material with a face-to-face system, and the learning methods used even lack the flexibility for students to learn independently. Based on the results of the interview with Ms. Temu, S.Pd grade, A teacher, obtained information that teaching materials developed by teachers are still limited; no one has produced a CTL video. Teaching materials commonly used are worksheets made by 


\section{Mudarrisa: Jurnal Kajian Pendidikan Islam, Vol. 12, No. 1, 2020}

publishers who even focused on the elaboration of the material and practice questions only, not according to needs and not under the conditions of the learning environment. A similar sentiment was also conveyed by the headmaster of Ubaidillah, S.Pd.I that in VI Islamic Elementary School Siti Sulaechah has never been developed CTL Natural Sciences video with a contextual approach by the teacher independently.

CTL videos are useful and practical use in the learning process, as research conducted by Dewi Atira et all in 2017 (Atira et al., 2017) and Anisah Kurniati in 2016 about developing CTL videos with a contextual approach, states that CTL videos are effectively used in learning (Kurniati, 2016). The developing CTL videos in this study apart from being the result of needs analysis, CTL videos have several advantages, including being able to be used independently by students, overcoming time constraints on face-to-face learning, can be developed by the teacher, and can be used as teaching materials in the face to face learning (Budiyono, 2018; Suwito, 2016). CTL videos can be used in schools in general, including in Elementary Schools/Schools Ibtidaiyah Negeri (MIN) Semarang.

Besides having several advantages, the video also has limitations including the preparation of video requires specific expertise, the success of a CTL video is influenced by its composer; the difficulty in determining graduation because the resolution of science questions by students varies in time, influenced by the ability and speed of each; and supporting learning resources are generally quite challenging to obtain because 
students must find it themselves (Muslich, 2007). The weaknesses of the video have been to minimize the possibility of problems in the development of videos and their use.

Problems, as mentioned above, it was essential to immediately find a solution that is by fulfilling teaching materials in the form of video science with a contextual approach. Because of this, it needed to conduct research and development with the title Development of CTL Learning Videos on Electrical Energy Materials for Class VI Students of Elementary School level or SD/MI.

\section{METHODS}

The design of this research was research and development. Research and development is a research method that is directed to produce products in certain areas of expertise and test the effectiveness of these products (Nasiroh, 2014). This study used the ADDIE development procedure, which stands for the stages of activities contained in the development model, which consists of Analysis, Design, Development, Implementation, and Evaluation. Analysis: analyze everything needed in development (Ngussa, 2014; Peterson, 2003). Design: creating a design or CTL video framework that will be developed in both layout and appearance. Development (product development): the development of CTL video teaching materials from the collection of materials, preparation, validation, revision, and production of CTL videos. Implementation; use CTL videos 


\section{Mudarrisa: Jurnal Kajian Pendidikan Islam, Vol. 12, No. 1, 2020}

developed in learning. Evaluation: evaluating the CTL video used concerning its effectiveness, practicality, and attractiveness in learning (Gayatri et al., 2018 Ismatunsarrah et al., 2020).

The subject of this study were grade VI students of Siti Sulaechah Islamic School Semarang that numbered 30 students. The data collection techniques used are interviews and questionnaires. The interview was used to obtain the information deals with the real condition and was used to analyze the necessity of developing the video electricity energy based on the CTL. The questionnaire was used to collect the data from the designing expert, the material expert, the user expert, and the experiment subject. Then, the result of the questionnaire was analyzed and was used as the guidelines to revise for gaining the perfection and the appropriateness of the developing product. The questionnaire was also shared with the students. It was the self-assessment and teacher's observation on the pre-test and post-test to know the improvement of environmental care character.

The data analysis method in this research is qualitative and quantitative data analysis. The qualitative data obtained from interviews with the head of the school and the Islamic elementary school teacher Siti Sulaechah Semarang are described descriptively; then, a conclusion is made. Quantitative data is used to (1) test the feasibility of CTL videos according to material and media experts; (2) knowing the practicality of the CTL video according to the teacher's response; and (3) interesting CTL videos according to students' responses. The analysis was carried out 
by calculating the average score of each aspect assessed and converting it to a qualitative value with the following classification.

\section{DISCUSSION}

The researcher analyzes the needs by conducting a preliminary study and analyzing everything needed for the development of the CTL video by observing curriculum documents, observing learning, and interviewing teachers and principals. Based on the results of interviews and observations conducted by researchers in the learning process obtained findings that the learning activities of IPA are still more often centered on teachers and emphasize the completion of subject matter with a face-to-face system, the learning method still lacks the discretion for students to actively learn independently. Many students still feel that science subject matter is more difficult to understand than other subject matter.

The science learning outcomes are also still unsatisfactory, the average is 67.05 , and the percentage of students who complete is $54.55 \%$ or does not meet the criteria thoroughly and does not meet classical completeness. The teaching materials available are still limited, while for students in natural science learning they still use a worksheet or Lembar Kerja Siswa (LKS) made by the outside publisher, because natural science textbooks are not yet available enough, also because LKS prices are lower even though sometimes the contents are not appropriate. Learning activities are still oriented to the completion of a considerable amount of 


\section{Mudarrisa: Jurnal Kajian Pendidikan Islam, Vol. 12, No. 1, 2020}

subject matter through face-to-face events, while the allocation of available time is insufficient. Educators need teaching materials in the form of CTL videos that can be used by students to learn independently.

Based on the aforementioned findings, the researcher conducted a development study by developing a CTL video of natural science learning with a contextual approach to the material collection and presentation of data for Class VI. The CTL video was expected to be effectively used in science learning to achieve classical completeness. The development of a CTL IPA (science education) video with a contextual approach to the material collection and presentation of data for class VI is as follows:

The analysis was carried out to gather information before the research was conducted through literature study and field studies. The literature study was used to analyze the needs in-depth to find relevant research literature. The needs of field studies are used to analyze the requirements in the field of developing animated images.

The design that was developed by the researcher was compiling teaching material in the form of video-based CTL material on electrical energy. The development of CTL-based animated image products includes the steps of (1) developing teaching materials, (2) guiding with validators, and (3) validation from media experts and material experts. The application of the development of CTL-based electric energy video is carried out on grade VI students of SD Islam Siti Sulechah Semarang. 
The evaluation was carried out to find out and measure whether the developed teaching materials are suitable for use. The assessment of the teaching media developed aims to improve and perfect the product after going through the implementation phase that is shown in Table 6 and Table 7 .

Table 6. Material Expert Test Feasibility Results

\begin{tabular}{clcc}
\hline No. & \multicolumn{1}{c}{ Aspect } & Average Score & Classification \\
\hline 1. & Video eligibility & 4,35 & Very good \\
2. & Presentation eligibility & 4,29 & Very good \\
3. & Language & 4,33 & Very good \\
\hline \multicolumn{2}{c}{ Average } & 4,33 & Very good
\end{tabular}

Table 7. CTL Video Feasibility Test Result by Material Expert

\begin{tabular}{clcc}
\hline No. & \multicolumn{1}{c}{ Aspect } & Average Score & Classification \\
\hline 1. & Content eligibility & 5,00 & Very good \\
2. & Presentation eligibility & 4,73 & Very good \\
3. & $\begin{array}{c}\text { Conformity with a } \\
\text { contextual approach }\end{array}$ & 4,67 & Very good \\
\hline & Average & 4,79 & Very good
\end{tabular}

Post-test results data of students with learning using CTL videos shows that as many as 23 of 30 or in percetage $76.67 \%$ of students achieve mastery learning and meet useful classification so that the application of learning CTL videos is declared effective. Analysis of the teacher's questionnaire responses to the practicality of the CTL IPA video obtained in Table 8. 


\section{Table 8. Results of CTL Video Practical Responses}

\begin{tabular}{|c|c|c|c|}
\hline No. & Aspect & Average Score & Classification \\
\hline 1. & Content of CTL Video & 4,40 & Very good \\
\hline 2. & Presentation of CTL Video & 4,75 & Very good \\
\hline 3. & Implementation & 4,60 & Very good \\
\hline & Average & 4,57 & Very good \\
\hline \multicolumn{4}{|c|}{$\begin{array}{l}\text { Based on Table } 3 \text { above, the results of the analysis of teacher } \\
4.57 \text { fulfilling the classification very well, so that the CTL video is }\end{array}$} \\
\hline
\end{tabular}

Table 9. Responses to CTL Video Withdrawal Results

\begin{tabular}{clcc}
\hline 1 & Content of CTL video & 4,19 & Good \\
\hline 2 & Presentation of CTL video & 4,57 & Very good \\
3 & Language & 4,17 & Good \\
4 & Attractiveness & 4,50 & Very good \\
5 & Expediency & 4,38 & Very good \\
\hline & Average & 4,36 & Very good \\
\hline
\end{tabular}

Based on table 4 above, the results of the analysis of students' responses about the attractiveness of the CTL video obtained an average score of 4.36, fulfilling the classification very well, so it is stated that the CTL video is enjoyable to use in learning. Based on the result of the pretest and post-test of the students' self-assessment and the teacher's 
observation, then the counting of paired sample tests was done by using SPSS 16.0, as shown in Figure 8.

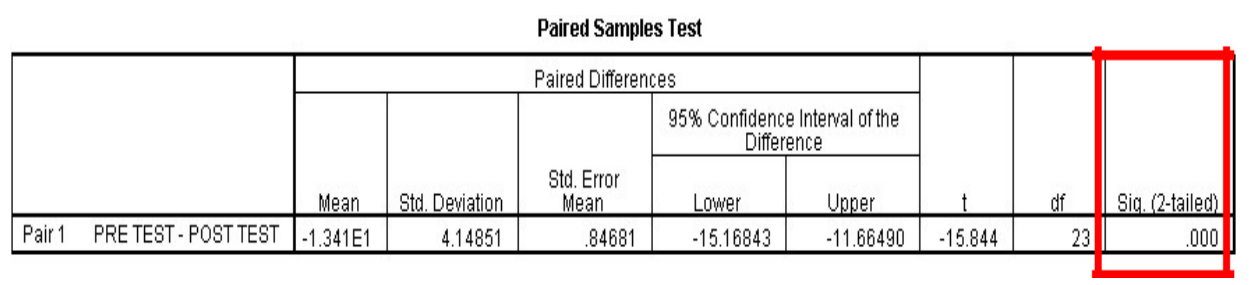

Figure 8. The test of paired sample t-test the assessment towards the Video CTL

It can be seen on the picture that the result of the test by using paired sample statistics of the students' self-assessment used questionnaire indicates the significance of the pre-test score $(2$ tailed), i.e., $0.00<0.05$ and the post-test score $(2$ tailed), i.e., $0.00, p<0.05(p=0.00<0.05)$. Then it can be concluded that the pre-test and post-test results have a significant change, while the analysis test for the teacher's assessment towards the video CTL is described in Figure 2.

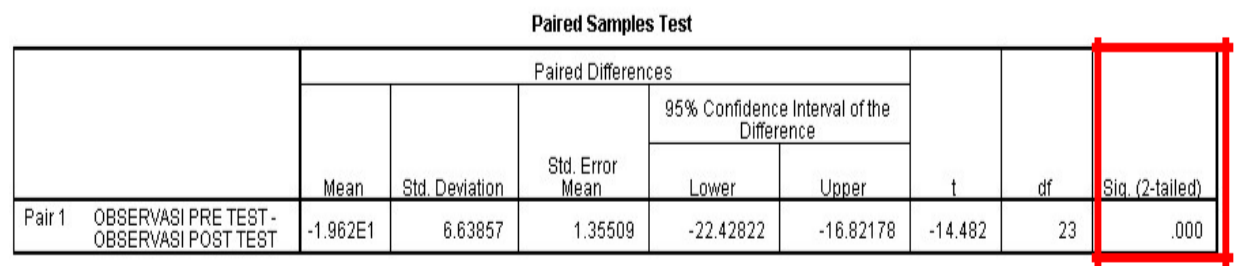

Figure 9.The test of paired sample test of the teachers' assessment towards the Video CTL

Figure 2 shows the teachers' assessment of the video CTL that was analyzed. It could be seen on the picture that the result of the test by using paired sample statistics of the questionnaire teacher's observation 
indicates the significance of the pre-test score ( 2 tailed), i.e., $0.00<0.05$ and the post-test score $(2$ tailed), i.e., $0.00,<0.05(p=0.00<0.05)$. Then it could be concluded that the pre-test and post-test results have a significant change.

Based on the description of statistics of the pre-test and post-test of the students' self-assessment and the teacher's observation, it is proven that the post-test is higher than the pre-test. Therefore it can be concluded that the development of the video based on the CTL Subtheme Electricity Energy can improve the environmental care character of the students. It appropriate with the results of research conducted by (Rahmawati et al., 2019). Rahmawati et al (2019) described that CTL could improve the motivation and character of the student, especially in vocational schools.

\section{CONCLUSION}

Referring to the needs analysis, which is the stage of research and development with ADDIE procedures, shows that the development of teaching materials in the form of CTL videos of natural science learning is needed to meet the needs of teaching materials in natural science learning at SD Islam Siti Sulaechah Semarang. Based on the feasibility test by material experts, an average score of 4.79 and media experts obtained 4.33 CTL videos that are declared valid or suitable for use in learning with the highest classification. CTL video practicality responses by teachers achieved an average score of 4.57, fulfilling the rating very well or 
practically used in learning. Reactions to the attractiveness of CTL videos by students obtained an average score of 4.36 , achieving very good or exciting classification used in education.

The result of the analysis test of the developing video based on CTL by using paired sample statistics on the students' self-assessment and the educator's observation indicates the pre-test significance ( 2 tailed) 0.00 $<0.05(\mathrm{p}=0.00<0.00)$. Based on this score, it can be concluded that the development of the video based on the CTL Subtheme Electricity Energy can improve the environmental care character of the students.

\section{REFERENCES}

Atira, A., Wahyono, U., \& Saehana, S. (2017). Pengembangan Modul Berciri Pendekatan Kontekstual Dalam Pembelajaran Fisika pada Materi Tekanan. JPFT (Jurnal Pendidikan Fisika Tadulako Online), 5(3), 41. https://doi.org/10.22487/j25805924.2017.v5.i3.8871.

Branch, R. M., \& Dousay, T. A. (2015). Survey Instructional Design Models. Indiana, United States of America: Association for Educational Communications and Technology.

Budiyono, F. (2018). The Effect of CTL Approach With Local Video Media Toward The Fourth Class Students in Social Studies at SDN Karangduak 2 Sumenep. 4, $34-42$.

Depdiknas. (2003). Undang-undang Republik Indonesia Nomor 20 Tahun

2003 tentang Sistem Pendidikan Nasional. Jakarta: Biro Hukum dan

Organisasi Sekretariat Jenderal Departemen Pendidikan Nasional.

Depdiknas. (2008). Teknik Penyusunan Video CTL. Jakarta: Direktorat 
Jenderal Manajemen Pendidikan Dasar dan Menengah.

Gayatri, T., Soegiyanto, H., \& Rintayati, P. (2018). Development of Contextual Teaching Learning-Based Audio Visual Adobe Flash Media to Improve Critical Thinking Ability of Geography Learning at Senior High School. IOP Conference Series: Earth and Environmental Science, 145(1). https://doi.org/10.1088/17551315/145/1/012004.

Gita, S. D., Annisa, M., \& Nanna, W. I. (2018). Pengembangan Modul IPA Materi Hubungan Makhluk Hidup dan Lingkungannya Berbasis Pendekatan Kontekstual. LENSA (Lentera Sains): Jurnal Pendidikan IPA, 8(1). $\quad$ Retrieved from http://jurnallensa.web.id/index.php/lensa/article/view/28.

Hamdani. (2011). Strategi Belajar Mengajar. Bandung: Pustaka Setia.

Irfan, M. (2012). Pengembangan Multimedia Interaktif Untuk Pembelajaran Mata Kuliah Konsep Dasar IPA I. II(1), 7-15. Retrieved from https://ojs.unm.ac.id/pubpend/article/view/1580/642

Ismatunsarrah, Ridha, I., \& Hadiya, I. (2020). Penerapan Model Contextual Teaching and Learning Pada Pembelajaran Materi Elastisitas Untuk Meningkatkan Hasil Belajar Siswa SMA. 4(1), 70_80. https://doi.org/10.24815/jipi.v4i1.14567.

Kosassy, S. O., Gistituati, N., Jama, J., \& Montessori, M. (2018). The Implementation of Contextual Learning Approach in E-learning based on Weblog toward Students Learning Achievements. Journal of Counseling and Educational Technology, 1(2), 59. https://doi.org/10.32698/0151.

Kurniati, A. (2016). Pengembangan Modul Matematika Berbasis Kontekstual Terintegrasi Ilmu Keislaman. Al-Khwarizmi: Jurnal Pendidikan Matematika Dan Ilmu Pengetahuan Alam, 4(1), 43-58. 
https://doi.org/10.24256/jpmipa.v4i1.251.

Muliani, M., \& Sumarsono, D. (2020). Contextual Teaching Learning (Ctl) Approach in Speaking Materials for Students' 21St Century Skill: Does It Have Any Effect? Jo-ELT (Journal of English Language Teaching) Fakultas Pendidikan Bahasa \& Seni Prodi Pendidikan Bahasa Inggris IKIP, 6(2), 99. https://doi.org/10.33394/joelt.v6i2.2362

Muslich, M. (2007). KTSP Berbasis Kompetensi dan Kontekstual. Jakarta: Bumi Aksara.

Ngussa, B. M. (2014). Application of ADDIE Model of Instruction in Teaching-Learning Transaction among Teachers of Mara Conference Adventist Secondary Schools, Tanzania. Journal of Education and Practice, 5(25), 1-11.

Peterson, C. (2003). Bringing ADDIE to Life: Instructional Design at Its Best. Journal of Educational Multimedia and Hypermedia, 12(13), 227-241. Retrieved from https://www.learntechlib.org/primary/p/2074/.

Rahmawati, L., Supardi, K. I., \& Sulistyaningsih, T. (2019). Contextual Teaching and Learning Integrated with Character Education to Improve Student's Motivation and Character in Concentration of Solutions Topic at .... Journal of Innovative ..., 8(3), 239-247. Retrieved from https://journal.unnes.ac.id/sju/index.php/jise/article/view/27910.

Selvianiresa, D., \& Prabawanto, S. (2017). Contextual Teaching and Learning Approach of Mathematics in Primary Schools. Journal of Physics: Conference Series, 895(1). https://doi.org/10.1088/17426596/895/1/012171.

Siti, E., Nurlela, F., \& Sujana, A. (2016). Penerapan Pendekatan Contextual Teaching and Learning Untuk Meningkatkan Hasil 
Belajar Siswa Pada Materi Energi Panas. Penerapan Pendekatan Contextual Teaching and Learning Untuk Meningkatkan Hasil Belajar Siswa Pada Materi Energi Panas, 1(1), 501-510. https://doi.org/10.23819/pi.v1i1.2979

Suwito. (2016). Pengaruh Contextual Teaching and Learning (CTL) dan Media Video Terhadap Motivasi Siswa Pada Pembelajaran Fiqh di MIN Muara Siban Pagar Alam. 1(2).

Suyawati, E., \& Osman, K. (2018). Contextual Learning: Innovative Approach towards the Development of Students' Scientific Attitude and Natural Science Performance. https://doi.org/DOI: 10.12973/ejmste/79329.

Tri Andarini, M. Masykuri, S. S. (2013). Pembelajaran Biologi Menggunakan Pendekatan CTL (Contextual Teaching and Learning) Melalui Media Flipchart dan Video Ditinjau dari Kemampuan Verbal dan Gaya Belajar. Bioedukasi, 6(2), 102-119.

Zakirman, Z., \& Hidayati, H. (2017). Praktikalitas Media Video dan Animasi dalam Pembelajaran Fisika di SMP. Jurnal Ilmiah Pendidikan Fisika Al-Biruni, 6(1), 85-93. https://doi.org/10.24042/jpifalbiruni.v6i1.592. 